\title{
Mindfulness and Compassion Strategies on Elite Soccer: Conceptualization of Mindfulness-Based Soccer Program (MBSoccerP)
}

\author{
Bruno Carraça*1, Sidónio Serpa ${ }^{1}$, António Rosado ${ }^{1}$ and Joan Palmi Guerrero ${ }^{2}$ \\ ${ }^{1}$ Faculty of Human Kinetics, Lisbon University, Portugal \\ ${ }^{2}$ National Institute of Physical Education of Catalonia (INEFC), Spain \\ *Corresponding author: Bruno José de Oliveira Carraça, Faculty of Human Kinetics, Lisbon University, Portugal
}

\section{ARTICLE INFO \\ Received: 幽 February 01, 2019 \\ Published: 幽 February 08, 2019}

Citation: Bruno C, Sidónio S, António R, Joan Palmi G. Mindfulness and Compassion Strategies on Elite Soccer: Conceptualization of Mindfulness-Based Soccer Program (MBSoccerP). Biomed J Sci \& Tech Res 14(2)-2019. BJSTR. MS.ID.002528.

Keywords: MBSoccerP; Sport Performance; Elite-soccer athlete's; Mindfulness; Self-Compassion
ABSTRACT

The difference between success and failure has become increasingly smaller in sport. A "third wave" approach in sport psychology, is been recently used for the first time to increase the performance level of the elite athletes with very well-defined programs. Study findings yielded that high-level athlete's meta-awareness and effective refocusing training by mindfulness-based programs were identified as important factors on performance training and competition.

Objectives: Explore the conceptualization and implementation of the Mindfulness-Based Soccer Program (MBSoccerP) to optimize mindfulness, compassion in the elite soccer performance. Secondary aims are: understand the relationship between attributes of mindfulness traits and self-compassion - the impact on the state of sports performance and dispositional flow; the relation between psychological symptoms, experiential avoidance and consequent effect on the level of anxiety and sports performance.

Methods: Letter to editor was conduct based on scientific publications and was retrieved from the PUBMED, MEDLINE, PsycINFO, Cochrane, ISI-Web of Science databases searched from 1985 to 2018. The main references cited in reviews were also included in the review to ensure that no relevant studies were excluded. The main search terms were mindfulness based interventions, sport performance, soccer, flow state, self-compassion, in different combinations as needed.

Results: The letter to editor allowed documenting advantages in participating in the Mindfulness- Based Soccer Program MBSoccerP with increase the attributes related to mindfulness, higher levels of self-compassion, acceptance flow state, sport performance, a lower overall index of psychopathological symptoms and physiological response to stress, less suppression of thoughts.

Conclusions: Study findings yielded could suggest that MBSoccerP can be helpful to enhance performance in sport.

\section{Introduction}

The sports performance can be thought as a noun or verb. As a noun, describes an isolated event where the athlete presents the development of a specific set of knowledge, skills and abilities. As a verb, describes the process of developing an action plan for the implementation of psychological and physical skills during an event. Thus, the performance means using the knowledge, skills or abilities, not just possess them [1-3]. The difference between success and failure has become increasingly smaller in sport. A "third wave" approach in sport psychology, is been recently used for the first time to increase the performance level of the elite athletes with very well-defined programs [1]. Study findings yielded that highlevel athlete's meta-awareness and effective refocusing training by 
mindfulness-based programs were identified as important factors on performance training and competition [4].

\section{Mindful-Compassion Approach and Sport}

Jon Kabat-Zinn and colleague's [5] are the first on record to use mindfulness meditation training within sport. Rowers preparing for the Olympics independently practiced mindfulness meditation (using guided tapes once or twice per day, and for fifteen-minute sessions) for two to seven weeks prior to the Olympic Games. Once per week group meditation training sessions were also provided. Kabat-Zinn et al. [5] reported that some of the U.S. Olympic team rowers who medaled reported the usefulness of mindfulness meditation in helping them optimize performance when racing. More recently, another group of researchers reported initial beneficial findings from mindfulness meditation for sport intervention [6]. Recently, mindfulness training has gained traction as a viable alternate approach to prepare athletes for optimal performance [5,7-10].

A mindfulness emphasis includes accepting psycho-emotional experience. Conceptually, mindfulness is about paying attention in a particular way, on purpose, non-judgmentally, in the present moment. Being in the present, which means not dwelling on the past participating future events such as winning or losing. In fact, when athletes describe being in the zone, they often describe a sense of being fully aware and on the present moment [5]. Mindfulnessbased interventions teach tolerance and acceptance of negative thoughts, feelings and emotions. This differs from the traditional implementation of psychological skills training in sport psychology, with the main skills including goal setting, arousal regulation, visualization, and self-talk. Such cognitive behavioral interventions are focused primarily on intentionally controlling one's thoughts, feelings and behaviors, and not regulate them as a mind mode of being $[9,10]$.

Mindful individuals perceive barriers or distractions as less relevant or bothering [11]. Moreover, mindful student athletes have a high sense of control and use positive self-talk [11]. Relationships between behavior-related cognitions and exercise may become stronger among mindful athletes [12]. Taking part in mindfulness training was found to influence a sense of control among athletes [13]. Mindfulness reflects a rather general tendency to respond in an insightful and open manner [14] and it may constitute one of the personal resources promoting stronger selfefficacy, and therefore, may indirectly predict sport outcomes. According to the models explaining sport performance there is a relation between self-regulatory beliefs, such as self-efficacy, and mindfulness. Mindfulness is likely to prompt self-regulatory cognitions. Furthermore, dispositional mindfulness (described as the tendency to be mindful in everyday life) is directly related to sport performance [1].

Crucial traits of mindfulness are nonjudgmental acceptance, openness to experiences, and insight [14]. Mindfulness contributes to both high levels of awareness and acceptance of in the moment reality [15]. Aligned with the core tenant of mindfulness is the concept of acceptance, which can be conceptualized as "taking a stance of nonjudgmental awareness and actively embracing the experience of thoughts, feelings and bodily sensations as they occur" [16].

The hypothesized link between mindfulness, compassion and performance may refer to the altering perceptions of barriers and sense of control over oneself and the environment. Conceptually, self-compassion aids in changing maladaptive thoughts, feelings and behaviors by allowing and individual to evaluate the self without self-condemnation, promoting more accurate perceptions of the situation [17]. Research in psychology show that self-compassion may play an important role in emotion regulation, and also show associations with a variety of adaptive outcomes, including life satisfaction, happiness, positive affect, mastery goals, and negative associations to self-criticism, anxiety, depression, rumination, perfectionism [18,19]. Despite the dearth of self-compassion literature and interventions research in sport, there are some studies inside and outside the sport context that have examined the effectiveness and impact of self-compassion interventions. Overall, the evidence suggest that self-compassion may protect against negative cognitions, emotions and behaviors, positioning it strongly for consideration in terms of potential application in sport domain. For example, studies have found that self-compassion was negatively related to shame proneness, social physique anxiety, fear of failure and fear of negative evaluation and support the idea that self-compassion could be particularly useful for athletes dealing with dysfunctional self-conscious emotions and self-evaluative thoughts and behaviors related to appearance and performance [20]. Also was found that self-compassion was negatively related to negative affect and several perfectionism components such as concern over mistakes, doubts about actions, and perceived coach pressure [21]. Taken all together, mindfulness and self-compassion have potential to be applied to different sport areas and domains, where athletes seem to have difficulties with coping, dealing with negative emotions and cognitions, self-criticism, rumination.

Hence, we will present the Mindfulness-Based Soccer Program (MBSoccerP) and its potential for enhance performance on elite soccer athletes. The protocol presented here comprehend nine 90-120-minute sessions, delivered weekly to groups of soccer athletes. The protocol is presented in its entirety, and no background in psychology, mindfulness, compassion, or on sport sciences is required to benefit from the content. However, when implementing MBSoccerP, trainers can use their knowledge in sport performance, clinical and sport psychology, mindfulness, compassion and experiential acceptance models, and the people they are training to tailor the intervention to participants 'unique competition needs.

\section{Methods}

Many sport psychology programs provide a basic outline of various mental skills that elite athletes can use to improve their 
sports work and help their team goals; however, the MBSoccerP links mental skills with the concept of flow awareness, mindfulness, compassion, and psychological flexibility as a change skill, which is the tool that allows on the game a quick mental decision to be add that radically change a thought process to enhance performance. The MBSoccerP try to be a powerful vehicle for soccer players change because, at list, brings the athlete to the only crucial game moment of importance- the present moment they play on the pitch, and also try to fit both a way of being or living and it is also a tool on can use to build compassion flow and mental flexibility.

MBSoccerP training athletes to look at a range of possibilities and then choosing the best mental approach or decision for their game situation. Hence, MBSoccerP training optimize mindfulcompassion key steps that needs to be used by soccer players to experience the most of the traditional psychological skills tools like positive and negative thinking, flow, self-talk, goal setting, imagery and recovery.

\section{Design Program (MBSoccerP)}

The MBSoccerP program was developed for elite soccer athletes. This study represents a first step to establish the role of

Table 1: Mindfulness-Based Soccer Training Structure (MBSoccerP).

\begin{tabular}{|c|c|c|c|}
\hline Sessions & Key concepts/Learning Goals & Experiential and Psycho-educational Training & After-Session Assignment \\
\hline $\begin{array}{l}\text { 1- Introduction to MB- } \\
\text { SoccerP Mindfulness } \\
\text { and sports }\end{array}$ & $\begin{array}{l}\text {-Definition of Mindfulness; } \\
\text {-Definition of Flow } \\
\text {-Stress:Responding vs. Reacting } \\
\text { to Stimulus; } \\
\text {-Awareness the best mental tool; } \\
\text { - Attention; } \\
\text { - The mindful athlete }\end{array}$ & $\begin{array}{l}\text {-3 Minutes meditation } \\
\text { - Mindful breathing } \\
\text { - Mindful eating }\end{array}$ & $\begin{array}{c}\text { - Breath Meditation } \\
\text { - STOP technique } \\
\text { - Check in to informal and for- } \\
\text { mal practice } \\
\text { - Selected pre, match and post- } \\
\text { match worksheets } \\
\text { - Simple Awareness and/or } \\
\text { Mindful Eating }\end{array}$ \\
\hline $\begin{array}{l}2 \text { - Mindfulness of the } \\
\text { Body and mind- self- } \\
\text { talk }\end{array}$ & $\begin{array}{l}\text { - Body as an anchor to present/ } \\
\text { conduit for experience; } \\
\text { - Pleasant \& Unpleasant } v s \text {. } \\
\text { mindfulness and positive \& neg- } \\
\text { ative thinking experiences; } \\
\text { - Automatic pilot and sport } \\
\text { mechanics }\end{array}$ & $\begin{array}{l}\text { - Body Scan } \\
\text { - Raisin exercise } \\
\text { - The mindfulness solution: Aware, Accept and Action } \\
\text { mindfulness and self-talk: red thoughts means stop; } \\
\text { yellow is neutral and green is go ("I can do it"); } \\
\text { - Metaphor feed the tiger/unwelcome party guest }\end{array}$ & $\begin{array}{l}\text { - Body Scan } \\
\text {-Selected Readings/worksheets } \\
\text { Remember and repeat: Aware, } \\
\text { Accept and Action } \\
\text {-Body Scan, Sitting Meditation. } \\
\text { - Pleasant Events Calendar }\end{array}$ \\
\hline $\begin{array}{l}3 \text { - Mindfulness and } \\
\text { Goal Setting versus } \\
\text { Process Goals }\end{array}$ & $\begin{array}{l}\text { - How mind hold the body back; } \\
\text {-Goals and Values; } \\
\text { - Performance values }\end{array}$ & $\begin{array}{l}\text {-Process goals exercise- ARMS: Action oriented, Realistic, } \\
\text { measurable; sequential } \\
\text { Performance values and value-driven behavior: } \\
\text { Mind is not your friend, and thank your mind, the voice } \\
\text { in my head. } \\
\text { Mindful yoga } \\
\text { Smart Goals: } \\
\text { Soothing-Supportive; Specific; Meaningful; accountable/ } \\
\text { attach/Associate; resources; Time. }\end{array}$ & $\begin{array}{l}\text { - Kindness Meditation } \\
\text { - Meditation on Smart Phone } \\
\text { App/ email audio exercise } \\
\text {-Selected Readings/Worksheets } \\
\text { /defusion rate form } \\
\text { Mindful Yoga (Yoga 1), Body } \\
\text { Scan, Sitting. } \\
\text { - Unpleasant Events Calendar }\end{array}$ \\
\hline
\end{tabular}

Copyright@ Bruno José de Oliveira Carraça| Biomed J Sci \& Tech Res| BJSTR. MS.ID.002529.
MBSoccerP training as a tool for improve peak performance in sport $[2,4,7]$ and sport injury rehabilitation [22] and to evaluate the impact of the program. The MBSoccerP has 9 sessions, once weekly for 90/120 minutes, during 8 weeks. The content for each session was developed based on the modified Mindfulness-Based Stress Reduction (MBSR) [23], Mindfulness Acceptance and Commitment Program $[9,10]$ and Compassion Mind Training [24,25] material.

Main sessions have the following sequence: review previous session, homework and overall MBSoccerP; centering exercise; short introduction to the topic of the present session task focused exercise; hatha yoga/ stretching exercises (e.g. , centering, breath meditation, compassion imagery, defusion metaphors, values and goals, action plans, body scan and mindfulness meditation ) role plays, fill worksheets exercises and short talks and group discussion regarding their own reflections and experiences that were related to session's topic plan for future practice; at the end of each session, the participants are given homework assignment that was given presently or sent electronically to each player's e-mail address; mindful-compassion meditation. A more detailed MBSSoccerP content of the nine main topics covered in each session of the program is outlined in Table 1. 


\begin{tabular}{|c|c|c|c|}
\hline $\begin{array}{l}4 \text { - Building a Mindful- } \\
\text { ness Practice }\end{array}$ & $\begin{array}{l}\text { - Formal vs. informal practice } \\
\text {-Integrating practice and com- } \\
\text { petition } \\
\text {-Finding a home in the body } \\
\text { - Helpful practice for athletes } \\
\text { Commitment } \\
\text { Thoughts }\end{array}$ & $\begin{array}{l}\text { - Introducing mindful yoga for beginners } \\
\text {-Mindfulness of thoughts } \\
\text { - Mindful yoga }\end{array}$ & $\begin{array}{c}\text { Noting Meditation } \\
\text {-Relax, Ground, and Clear } \\
\text { Meditation } \\
\text {-Mediation on thoughts, Smart } \\
\text { Phone App/ email audio } \\
\text { exercise } \\
\text {-Selected Readings/ Worksheets } \\
\text { STOP: The One Minute Breath- } \\
\text { ing Space } \\
\text { Mindful Yoga (Yoga 2) and } \\
\text { Sitting }\end{array}$ \\
\hline $\begin{array}{l}5 \text { - Emotions, meaning } \\
\text { in sports life. Radical } \\
\text { acceptance }\end{array}$ & $\begin{array}{l}\text {-What are emotions and physi- } \\
\text { cal sensations; } \\
\text {-No Bad or shameful emotions } \\
\text {-Identifying/ labeling to miti- } \\
\text { gate impact; } \\
\text { Experiential avoidance } \\
\text { - Emotion lifespan; } \\
\text { - Mindfulness of emotions pre, } \\
\text { match, post-match }\end{array}$ & $\begin{array}{l}\text { - Finding a home in the body } \\
\text { Mindful yoga } \\
\text {-Values and committed action } \\
\text { Importance of acceptance versus resignation } \\
\text { Letting go } \\
\text { RAIN four step process: Recognize, Allow, Investigate, } \\
\text { and Non-Identification }\end{array}$ & $\begin{array}{l}\text {-Finding a home in the body } \\
\text {-Creating a Practicing commit- } \\
\text { ted action } \\
\text { Everything is perfect as it is } \\
\text {-Ongoing formal and informal } \\
\text { practice }\end{array}$ \\
\hline $\begin{array}{c}6 \text { - Mindfulness and } \\
\text { imagery }\end{array}$ & $\begin{array}{l}\text { Flow } \\
\text { Exposure } \\
\text { Sport mindfulness } \\
\text { Common problems } \\
\text { Focus on the task }\end{array}$ & $\begin{array}{c}\text { Mindful yoga } \\
\text { Imagery as a tool to. Recall success; Rehearse a game } \\
\text { plan; remain focused; remind your goal } \\
\text { Compassion imagery exercise on sport context. } \\
\text { Awareness of your best performance. } \\
\text { Review of 3 A's of mindfulness: Aware, Accept and Action }\end{array}$ & $\begin{array}{l}\text { Ongoing practice } \\
\text { Compassion imagery } \\
\text { Remember and repeat: Aware, } \\
\text { Accept and Action } \\
\text { Selected pre, match and post- } \\
\text { match worksheets } \\
\text { Body Scan, Sitting, Yoga }(+ \\
\text { Mountain or Lake Med.) }\end{array}$ \\
\hline $\begin{array}{l}\text { 6a - Silent mindful } \\
\text { running and self-com- } \\
\text { passion }\end{array}$ & & $\begin{array}{l}\text { Silent Mindful Walking/mindful running in nature (90- } \\
120 \text { minutes) } \\
\text { The compassionate letters }\end{array}$ & $\begin{array}{l}\text { Ongoing practice } \\
\text { - Mindfulness in breathing } \\
\text { one-minute meditation } \\
\text { - Mindful walking } \\
\text { - Body scan } \\
\text { Receiving affection from friends, } \\
\text { strangers and enemies } \\
\text { - Metta (to others and oneself) }\end{array}$ \\
\hline
\end{tabular}




\begin{tabular}{|c|c|c|c|}
\hline $\begin{array}{l}7 \text { - Mindfulness Accep- } \\
\text { tance and Compas- } \\
\text { sion-Body connection } \\
\text { \& athlete recovery }\end{array}$ & $\begin{array}{l}\text { Ways of training compassion: } \\
\text { receiving compassion, showing } \\
\text { compassion to oneself and to } \\
\text { others Fear of compassion. } \\
\text { Shame }\end{array}$ & $\begin{array}{c}\text { Mindfulness of emotions } \\
\text { Mindful yoga } \\
\text { Loving Kindness Exercise/compassion flow/imagery } \\
\text { The compassionate letters experience review }\end{array}$ & $\begin{array}{l}\text { Ongoing practice } \\
\text { Breathing practice - 3-minute } \\
\text { breathing space in pairs - Clos- } \\
\text { ing metta } \\
\text { Body Scan, Sitting, Yoga (+ } \\
\text { Lovingkindness) } \\
\text { Mindful Eating, STOP, etc }\end{array}$ \\
\hline 8 - Ending MBSoccerP & & $\begin{array}{c}\text { Body scan review } \\
\text { Compassion sport imagery } \\
\text { Defusion, values, flow and acceptance review. Mindful } \\
\text { yoga }\end{array}$ & $\begin{array}{c}\text { Enhance ongoing MBSoccerP } \\
\text { practice }\end{array}$ \\
\hline
\end{tabular}

Several specific interventions were used. For example, Mindful Walking and Mindful Breathing are meditations that involve focusing on a specific action or experience of the body in the present moment. The STOP exercises connect emotions and thoughts to the body when experiencing stress; Body Scan involves concentration on specific areas of the body; and Self Compassion Letters and Loving Kindness is a meditation on positive wishes and intention for one's self. Each session also contained a meditation to complete throughout the week and self-guided readings. Additionally, worksheets and email audio applications were introduced to participants could track their mindful compassion training, performance and complete corresponding meditations between each session.

Here are a few key components of practicing mindfulness, compassion and acceptance that key we have identified, set in the context of soccer:

a) At the beginning of the game, on the beginning of second half: Pay close attention to your breathing, especially when you're feeling intense emotions, nerves or frustration. Use the breath as an anchor to come out of your mind and into the body. Re-center yourself on the present. Decide to accept the feelings you have, let them go, don't judge or rebuke yourself. Once you do this you will be able to smile and enjoy the situation you find yourself in - embrace the challenge.

b) When about to hit a corner, free kick or on a penalty kicks: Notice - really notice - what you're sensing in a given moment, the texture of the pitch below you, the sound of the ball, and the smells that ordinarily slip by without reaching your conscious awareness. At finals: Recognize that your thoughts and emotions are fleeting and do not define you. Accept they will happen and let them go. Having this insight can free you from negative thought patterns. Try focus into your body's physical sensations, from the cool breeze on your skin to the way your feet feel against the ground when you feed in a ball.

c) When dealing with a confrontational coach, president club or another player when faced with a tense and difficult conversation, imagine a divider between the situation and yourself; give yourself space. This space provided will give you room to focus on your body and relax the areas that are tense or tight. Do this while staying present in the situation i.e. don't rush ahead and compose your response or argument, simply breathe and stay with the moment. Get out of your own head and listen intently to the player or club president while still keeping an eye on your body's reactions. Accept the emotions you are feeling as normal. Take time with your response and be empathetic so as not to let the situation escalate. Finally, when a player is nervous before an important match out a match focus on your breath (or any part of your body that you feel most natural to focus on). Use this focus to bring you back into the present. Your breath is controllable, this point, focus on what is controllable and gently guide your attention back to this. Use it tactically on the flow game situations.

\section{Results and Discussions}

\section{Program Evaluation, Treatment Fidelity and Compliance}

The MBsoccerP have a pre and post-test evaluation and a brief written evaluation of the program where the participants answered open-ended questions about if and how they perceived that the program changed the ways they act or think inside the soccer $[2,26]$. To maintain the fidelity and consistency of to the MBsoccerP training contents the trainers are a clinic and sport psychologists, experienced mindfulness-based practitioners with training in Mindfulness-based interventions and $3^{\circ}$ CBT wave interventions on health, clinical and sport settings. In addition, in weekly workbooks participants were asked to complete a record of minutes meditated immediately after each home-meditation session. The main purpose of the interception forms was to encourage reflection on awareness of body sensations, but these forms also provided some information regarding adherence to MBSoccerP training through representing internalization of aspects of mindfulness, psychological flexibility and compassion [24,25]. Compliance was measured in the studies by noting class attendance and assessing the frequency and duration of formal mindfulness and compassion practice and the frequency of informal mindfulness practice (i.e. breath awareness and daily life mindfulness). 


\section{Conclusion}

The Mindfulness- Based Soccer Program (MBSoccerP) seems to have impact in increasing the attributes of mindfulness, compassion, psychological flexibility, and in which terms that mediates dispositional flow and peak performance on elite soccer players. This program seems to work as a stress and suppression thoughts buffer.

MBSoccerP is unique being one of the first mindful-compassion based intervention programs available that was developed especially for elite soccer athletes. Is at the end, a step-by step program in cultivating fundamental mindfulness, compassion and psychological flexibility (ACT) skills and then executing those skills within their athletic endeavors. The research [2,7,26,27] and experiences with the program have made quite excited about its sport performance enhancement. Worthwhile change is rarely easy, so engagement on MBSoccerP training try to be a new way of approaching Elite soccer sport.

Birrer et al. [1] and Gardner and Moore [9,10] suggested that increases in mindfulness may modify the nature of the experience of emotions and cognitions such as anxiety and rumination rather than lessen them. The results of the study have practical implications for athletes and coaches. Together with findings of previous research, the results suggest that training athletes in MBSoccerP increases their mindfulness, experimental acceptance, self-compassion, flow and peak performance. Increasing athletes' mindfulness, compassion and psychological flexibility has implications for athletes' experience during sporting events as well as aspects of their life outside of sport [28-30]. Further, the results of the study indicate that sport-specific mindfulness- based training increases athletes' experience of flow, a state beneficial for peak performance on elite athletes [2,27].

\section{References}

1. Birrer D, Rothlin P, Morgan G (2012) Mindfulness to enhance athletic performance: Theoretical considerations and possible impact mechanisms. Mindfulness 3(3): 235-246.

2. Carraça B, Serpa S, Palmi G, Rosado A (2018) Enhance Sport Performance of Elite Athletes: The Mindfulness-Based Interventions. Cuadernos de Psicologia del Deporte 18(2): 79-109.

3. Serpa S (2002) Treinador e atleta: A relação sagrada. In B Becker (eds.); Psicologia aplicada ao treinador esportivo. Rio Grande do Sul: Editora Freevale, p. 18-67.

4. Solé S, Carraça B, Serpa S, Palmi J (2014) Aplicaciones del Mindfulness (Conciencia Plena) en Lesión Deportiva. Revista de Psicología del Deporte 23(2): 501-508.

5. Kabat-Zinn J, Lipworth L, Burney R (1985) The Clinical Use of Mindfulness Meditation for the Self-Regulation of Chronic Pain. Journal of Behavioral Medicine 8(2): 163-190

6. Thompson RW, Kaufman KA, De Petrillo LA, Glass CR, Arnkoff DB (2011) One-year follow-up of Mindful Sport Performance Enhancement (MSPE) with archers, golfers, and runners. Journal of Clinical Sport Psychology 5(2): 99-116.

7. Carraça B, Serpa S, Rosado A, Palmi J (2018) The Mindfulness - Based Soccer Program (MBSoccerP): Effects on Elite Athletes. Cuadernos de Psicología del Deporte 18(3): 62-85.
8. De Petrillo L, Kaufman K, Glass C, Arnkoff D (2009) Mindfulness for Long-Distance Runners: An Open Trial Using Mindful Sport Performance Enhancement (MSPE). Journal of Clinical Sport Psychology 3(4): 357376.

9. Gardner FL, Moore ZE (2006) Clinical sport psychology. Human Kinetics, Champaign, Illinois, USA.

10. Gardner FL, Moore ZE (2012) Mindfulness and acceptance models in sport psychology: A decade of basic and applied scientific advancements. Canadian Psychology/Psychologie Canadienne 53(4): 309-318.

11. Kee YH, Wang CKJ (2008) Relationships between mindfulness, flow dispositions and mental skills adoption: A cluster analytic approach. Psychology of Sport and Exercise 9(4): 393-411.

12. Hagger MS, Chatzisarantis NLD (2007) Intrinsic motivation and selfdetermination in exercise and sport. Human Kinetics, Champaign, Illinois, USA.

13. Aherne C, Moran AP, Lonsdale C (2011) The effect of mindfulness training on athletes' flow: An initial investigation. The Sport Psychologist 25: 177-189.

14. Walach H, Buchheld N, Buttenmuller V, Kleinknecht N, Schmidt S (2006) Measuring mindfulness - the Freiburg Mindfulness Inventory. Personality and Individual Differences 40(8): 1543-1555.

15. Kabat-Zinn (1994) Wherever you go, there you are: Mindfulness meditation in everyday life. Hyperion, New York, USA pp. 278.

16. Hayes SC, Strosahl KD, Bunting K, Twohig M, Wilson KG (2004) What is acceptance and commitment therapy? Practical guide to Acceptance and Commitment Therapy. New Harbinger, Oakland, USA, p. 3-29.

17. Neff KD (2003) Self-compassion: An alternative conceptualization of a healthy attitude toward oneself. Self and Identity 2: 85-102.

18. Leary MR, Tate EB, Adams CE, Allen AB, HancockJ (2007) Self-compassion and reactions to unpleasant self-relevant events: The implications of treating oneself kindly. J Pers Soc Psychol 92(5): 887-904.

19. Neff KD, Rude S, Kirkpatrick K (2007) An examination of self-compassion in relation to positive psychological functioning and personality traits. Journal of Research in Personality 41: 908-916.

20. Mosewich AD, Kowalski KC, Sabiston CM, Sedgwick WA, Tracy JL (2011) Self-compassion: A potential resource for young women athletes. Journal of Sport \& Exercise Psychology 33(1): 103-123.

21. Mosewich A, Crocker P, Kowalski K, Delongis A (2013) Applying selfcompassion in sport: an intervention with women athletes. Journal of Sport \& Exercise Psychology 35(5): 514-524.

22. Palmi J, Planas A, Solé S (2018) Intervención mindfulness de rehabilitación de un deportista lesionado: Caso en futebol profesional. Revista de Psicologia del Deporte 27(1): 115-122.

23. Kabat Zinn J (2013) Full catastrophe living: Using the wisdom of your body and mind to face stress, pain and illness. Bantam/Random House.

24. Gilbert P (2009) The Compassionate Mind: A New Approach to Life's Challenges. Constable Robinson.

25. Tirch D (2010) Mindfulness as a context for the cultivation for compassion. International Journal of Cognitive Psychotherapy 3(2): 113-123.

26. Carraça B, Serpa S, Rosado A, Palmi J (2019) A pilotstudy of a MindfulnessBased Program (MBSoccerP): The potential role of mindfulness, selfcompassion and psychological flexibility on flow and elite performance in soccer athletes. Revista Iberoamericana de Psicologia del Ejercicio y el Deporte 14(1): 34-40.

27. Carraça B, Serpa S, Palmi J, Magalhães C (2015) Mindfulness based stress reduction program (MBSR-SP) on elite soccer players: Psychological inflexibility versus acceptance. Association for Contextual Behavioral Science, Berlin, Germany.

28. Demarzo M, Oliveira JMR, Silva AFD, Lessa Moreno I, Barceló A, et al. 
(2015) Mindfulness applied to high performance athletes: A case report Actas Espanholas de Psiquiatria 43(1): 1-90.

29. Haase L, April CM, Falahpour M, Isakovic S, Simmons AN, et al. (2015) A pilot study investigating changes in neural processing after mindfulness training in elite athletes. Front Behavioral Neuroscience 9: 229.

\section{ISSN: 2574-1241}

DOI: 10.26717.BJSTR.2019.14.002529

Bruno José de Oliveira Carraça. Biomed J Sci \& Tech Res

(C) (i) This work is licensed under Creative

Submission Link: https://biomedres.us/submit-manuscript.php
30. Kauffman K, Glass C, Arnkoff D (2009) Evaluation of Mindful Sport Performance Enhancement (MSPE): A new approach to promote flow in athletes. Journal of Clinical Sports Psychology 4: 334-356.

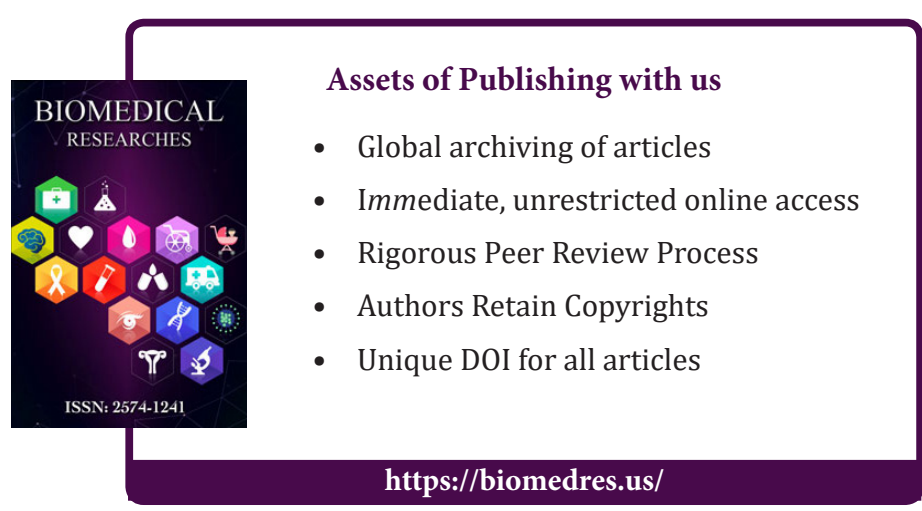

